International Journal of Law and Politics Studies (IJLPS)

ISSN: 2709-0914

DOI: $10.32996 /$ ijlps

Website: https://al-kindipublisher.com/index.php/ijlps

\title{
Optimizing The Role of the General Election Commission in Realizing Democratic Elections in Indonesia
}

\author{
Ta'mirotul Biroroh \\ Master of Constitutional Law UIN Sunan Ampel Surabaya, Indonesia \\ $\square$ Corresponding Author: Ta'mirotul Biroroh, E-mail: tbiroroh@gmail.com
}

\section{ARTICLE INFORMATION \\ Received: 15 October 2021 \\ Accepted: 16 November 2021 \\ Published: 29 November 2021 \\ DOI: $10.32996 /$ ijlps.2021.3.2.5}

\section{KEYWORDS}

General Election Commission, Election, and Democracy

\section{ABSTRACT}

The mechanism for transferring people's sovereignty is carried out through general elections to elect leaders and representatives of the people who will be mandated to carry out state and government affairs in accordance with the provisions contained in the legislation. One of the interesting developments from the point of view of the Indonesian state administration began when Indonesia experienced a transitional period of general elections (elections) which are one of the main pillars of democracy. In Indonesia, the existence of an election management body has existed since the 1955 general election until now. In every course of political history, Indonesia has several different institutional models of election management from time to time. The General Election Commission in Indonesia it is called Komisi Pemilihan Umum (KPU) is an institution that carries out the function of organizing elections in Indonesia. In addition to the KPU, there are institutions that also play an important role in the implementation of elections and are closely related to the existence of the KPU, namely survey institutions that carry out quick count processes. The survey institutions in a number of developing countries, especially those that are actively building democracy, are also not a little doubted by their moral honesty, at least being sued with a critical attitude such as the existence of a poll on the existence of a political survey institution, which has resulted in an attitude of uncertainty about the performance survey agency. This condition makes people less confident in the survey results which are considered no longer independent. It is proven that every time an election is held, a number of survey institutions seem to want to lead public opinion towards certain contestants. This is certainly very unfortunate considering that the survey results are one of the important instruments in democracy.

\section{Introduction}

It has been mutually agreed that Indonesia is a unitary state that upholds democratic values. The political will to organize the Indonesian state based on democratic principles is not something new in Indonesia. Since the establishment of the Unitary State of the Republic of Indonesia (NKRI), the founding fathers of the nation have had a political will based on democratic principles which are also contained in Pancasila and the 1945 Constitution.

The principle of democracy is implied in the fourth precept of Pancasila, namely "People led by wisdom in representative deliberation (The Constitution of The Republic of Indonesia of 1945). Article 1 paragraph 2 of the Republic of Indonesia Constitution of 1945 also explains that "sovereignty is in the hands of the people and is implemented in accordance with the Constitution (The Constitution of The Republic of Indonesia of 1945). Regarding the amendment of Article 1 paragraph (2) of the 1945 Constitution, Ali Safa'at stated that there are at least 5 (five) basic consequences of the change, one of which is the affirmation that the principle of democracy which is a form of people's sovereignty in its implementation must follow the principles of democracy. state of law culminating in the supremacy of the constitution (M. Imam Nasef,2019). In addition, Article 28 of the 1945 Constitution also

Copyright: (c) 2021 the Author(s). This article is an open access article distributed under the terms and conditions of the Creative Commons Attribution (CC-BY) 4.0 license (https://creativecommons.org/licenses/by/4.0/). Published by Al-Kindi Centre for Research and Development, London, United Kingdom. 
provides an explanation regarding the granting of independence to the people to unite and assemble as well as provide freedom of expression (Undang-Undang Negara Republik Indonesia Tahun 1945).

The mechanism for transferring people's sovereignty is carried out through general elections to elect leaders and representatives of the people who will be mandated to carry out state and government affairs in accordance with the provisions contained in the legislation. One of the interesting developments from the point of view of the Indonesian state administration began when Indonesia experienced a transitional period of general elections (elections) which are one of the main pillars of democracy. Democracy in a country is characterized by several things, including the existence of elections, freedom of the press, freedom of assembly and association, freedom of opinion, and the implementation of the law (Oktino Setyo Irawan, 2011). One of the early conceptions of democracy proposed by Joseph Schumpeter placed the holding of free and periodic elections as the main criteria for a political system to be called democracy (Joseph Schumpeter,2008).

Elections in Indonesia are held regularly every 5 (five) years with the aim of ensuring leadership regulation in both the executive and legislative branches so that there is no absolute leadership (Oktino Setyo Irawan, 2011). As explained earlier, elections in Indonesia are one of the democratic mechanisms to change leaders and representatives of the people who are directly elected by the people. With the direct election of people's representatives through the general election process, it is hoped that a government will get strong legitimacy from the people themselves so that a stable government can be realized accompanied by high support from the existing people.

Election activities are one of the agendas that attract enough attention and enthusiasm from the community so that the election becomes one of the strategic moments to provide political education for the community in order to mature the community. Arbi Sanit explained that related to the function of elections, namely forming the legitimacy of the authorities and also the government, forming representatives from people's politics, the circulation of the ruling elite, and political education (M. Yusuf A.R,2010).

Article 22 E paragraph (1) of the 1945 Constitution of the Republic of Indonesia provides an explanation regarding the implementation of elections, namely: "General elections are carried out in a direct, general, free, secret, honest and fair manner every five years". Article 22E paragraph (5) also provides an explanation that "General elections are held by a general election commission that is national, permanent and independent (Undang-Undang Dasar Negara Republik Indonesia Tahun 1945). Therefore, based on the 1945 Constitution of the Republic of Indonesia, the election organizer must be a commission that has a national, permanent, and independent character; free from the influence and interference of others.

The General Election Commission (KPU) as an election management body must always adhere to the applicable rules. In Law Number 7 of 2017 concerning General Elections, it is explained that the KPU is an independent institution in the Indonesian constitutional system that has the duties, authorities, and obligations as election organizers in accordance with the mandate contained in the legislation. It is explained in Article 7 of the law that, "in holding elections, the KPU is free from any party with regard to the implementation of its duties and authorities (Undang-undang Nomor 7 tahun 2017 tentang Pemilihan Umum). This shows that the KPU is an independent institution that has the freedom to carry out its duties and functions in organizing elections in accordance with the applicable laws and regulations. What is meant by the independence of the KPU is that the election organizers must be neutral and not take sides with anyone. In this case, the KPU must not be under the control of anyone, both political parties and state officials who show the interests of political parties or candidates for election participants (Jimly Asshiddiqie,2006). These parties have a direct or indirect interest in various decisions to be taken by the KPU as the election organizer. Therefore, the KPU must not be bound and must be free from the possibility of various influences from these parties.

Even though there are regulations regarding the independence of the KPU, it does not mean that this institution is free from interference from other parties as ideally expected. There are various efforts to weaken the independence of the KPU, especially through legislation, such as the making of a law that allows members of political parties to be the organizers of the election, as well as a law that stipulates that in organizing the Pilkada, the Provincial KPU and Regency/Municipal KPU have responsibilities to the DPRD. including the use of the budget. Another example relates to the provision that the results of consultations between the KPU and the government and the DPR in the process of drafting KPU regulations are binding (Pramono U. Tanthowi, 2010)

The emergence of various threats of intervention and co-optation is certainly a sensitive issue that can eliminate the spirit of independence from the KPU institution. These examples clearly show the impression that the independence of the KPU is not something that has been established, but continues to be the target of weakening by various political forces. This shows that the independence of the KPU is an arena of contestation between political actors (Christopher S. Elmendorf,2006).

In addition, regulations regarding elections are still far from expectations and there are still many weaknesses and problems. This is because in it there is still material that as a whole has not been able to provide certainty of an orderly configuration. One example 
is the inconsistent and uncertain arrangements for resolving electoral law issues, especially regarding the mechanism for resolving electoral disputes (Sri Warjiyati,2017). Another problem also occurs regarding the imbalance of relations between election management institutions that are not able to run effectively and efficiently. This is certainly a problem that has implications for the regularity of holding elections in Indonesia.

Based on the explanation that has been presented above, the discussion regarding the KPU institution is certainly a very interesting study in the review of state institutions, for the sake of creating a democratic Indonesian state in accordance with the mandate that has been stated in the Indonesian state legislation.

\section{Problem Statement}

1. How is the existence of the General Election Commission (KPU) in the Indonesian state administration?

2. What are the duties, authorities, and obligations of the General Elections Commission (KPU) in the Indonesian state administration?

\section{Research Method}

This research is normative legal research using a statutory approach and a conceptual approach. The statutory approach is carried out to examine various regulations governing the authority of the General Election Commission in Indonesia. The conceptual approach is used to understand the concept of democracy in a country.

Sources of data from this study were obtained from secondary data sources. Secondary data sources consist of primary legal materials and secondary legal materials. Primary legal materials are materials sourced from statutory regulations. Secondary legal materials are materials in the form of literature books, legal journals, and the results of studies/research related to the issues discussed.

The procedure of data collection is done by a literature study. This literature study was conducted by reading, citing, and analyzing the laws and regulations, and literature related to the issues discussed.

Data processing is done by classifying the data and editing the data obtained. The data is classified and then an examination is carried out regarding the completeness of the data whether there is insufficient data or not.

The data obtained were then analyzed qualitatively by describing the data generated from the normative study in the form of a systematic explanation so that a clear picture of the problem under study could be obtained. From the results of the analysis, it is concluded inductively, namely a way of thinking that is based on specific facts and then concluded in general terms.

\section{The Existence of the General Elections Commission (KPU) In The Indonesian Constitution}

Along with the ongoing process of democratization in various parts of the world, more and more countries have an interest in organizing the electoral process in a neat, democratic and peaceful manner. Democracy as a political system has also undergone various developments in its application. Various models of democracy have emerged and this cannot be separated from various perspectives in giving the meaning of substantial democracy. The factors that make democracy experience various model developments are, among others, due to the creativity of political actors in various places in designing procedural democratic practices in accordance with the culture, history, and interests of each of them (Ni'matul Huda dan M. Imam Nasef,2017).

One of the interesting things to study in a democratization process in a country is related to the design in holding general elections to elect leaders or representatives of the people who will be given the mandate to run the wheels of government based on the people's vote. The authority to hold this general election is delegated to an election organizing body. The election management body or commonly referred to as the general election varies from one country to another. In fact, despite having similar functions, the structure of the general election organizing body in various countries can be divided into several types according to the level of independence, including; (1) independent, (2) part of the government which is supervised by an independent institution; and (3) run by the government (Shaheen Mozaar and Andreas Schedler,2002). Meanwhile, Lopez-Pintor added two other models: (4) variations of the first model: consisting of several bodies, all of which are independent; (5) Decentralized implementing agency ( Pramono U. Tanthowi,2010).

The first model of an independent EMB, as implied by its inherent nature, is a branch of executive power that is independent and has full responsibility for administering elections, and is often also responsible for policymaking and decision-making related to the electoral process. This institutional model is embraced by most of the new democracies and has strong traditional roots in Latin America (Pramono U. Tanthowi,2010) 
Meanwhile, in mixed-model EMBs, the government conducts elections under the supervision of an independent, collective body, generally consisting of judges and legal professionals, representatives of political parties, or a mix of both. This type of institution commonly referred to as the "French Model", generally has regulatory, supervisory, and judicial powers. This model is widely adopted by Mainland European countries, a large number of African countries (which are generally former French colonies), as well as several other countries (Pramono U. Tanthowi,2010).

On the other hand, in the third model, elections are fully implemented by the government. This model was adopted by several Western European countries, as well as a number of countries in South Asia, the Pacific, the Caribbean, the Middle East, and parts of Africa. In addition, in the fourth model, the EMB is responsible for both directive and managerial functions. In general, this model consists of two organizations: one of which functions as an implementer and the other functions for the formulation of regulations and dispute resolution. The final model is a decentralized EMB which has limited lines of coordination and supervision with institutions at the central level. This model can take the form of independent, part of the government, as well as professional associations (Pramono U. Tanthowi,2010)

The difference in the level of independence of each model will of course affect the level of public confidence in the electoral process. Therefore, if an independent election administrator can carry out the stages of the election with greater impartiality, then such an institutional model can lead voters to believe that the election was held fairly for all candidates. However, it must be acknowledged that the institutional model for independent EMBs is indeed a new finding, and tends to be introduced in new democracies that are still vulnerable (Pramono U. Tanthowi,2010)

Although EMBs can be categorized into a number of models, no two institutions are exactly the same in every country. This is because the choice of election management institutions as the general election system is a product of the history of a nation and has its own political roots and legal traditions. In many cases, the institutional model was strongly influenced by the regime of the colonial state. Although in many other examples, there are also countries that are trying to completely eliminate their colonial heritage.

In Indonesia, the existence of an election management body has existed since the 1955 general election until now. In every course of political history, Indonesia has several different institutional models of election management from time to time. During the New Order era, the election management body was fully controlled by the government, both in the executive (election implementing agency) and the judiciary (election supervisory agency) (Parulian Donald,1997).

This is understandable because elections during the New Order basically had almost nothing to do with democracy. On the other hand, elections only serve as a legitimizing factor for the regime and provide a pretext for international recognition. Nevertheless, the New Order regime has started a tradition of procedural democracy that is quite consistent, as evidenced by regularly holding elections every five years starting from the 1971 election to the 1997 election as the last election in the New Order era (Nur Hidayat Sardini,2011). However, because the New Order regime has received a lot of criticism from various parties, when there are strong demands for the implementation of democratic elections in the Reformation era, one aspect that receives important attention to be fundamentally addressed is the model and institutional structure of the election administration, namely General Election Commission (KPU).

As stipulated in Article 7 of Law no. 7 of 2017 concerning General Elections, it is explained that "in holding elections, the KPU is free from any party related to the implementation of its duties and authorities (Undang-Undang Nomor 7 Tahun 2017 tentang Pemilihan Umum). This can be interpreted that the KPU in carrying out its duties is free from various interventions from any party. The independence of the KPU is certainly aimed at creating a clean and stable government, the public can channel their aspirations based on their conscience, as well as minimizing possible frauds in the election administration.

\section{Duties, authorities, and obligations of the general elections' commission (kpu) in the Indonesian constitution}

In order to ensure an orderly cycle of power, it is necessary to have a competent election management body and a mechanism for organizing elections that are held regularly, so as to ensure that there is democracy in a government and the interests of the entire community can be guaranteed. Jimly Asshiddiqie (2006) provides the formulation of the objectives of holding the election as follows (Didik Sukriono,2009)

a. Provides the possibility of an orderly and peaceful shift in government leadership

b. Provide the possibility of a change of position that will later be a representative of the people and guarantee all the interests of the people in the representative body

c. Carrying out the principles of sovereign citizenship, and

d. Ensuring the implementation of principles on the human rights of citizens. 
KPU is an institution that carries out the function of an election organizer in Indonesia. (UU No. 7 tahun 2017 tentang Pemilihan Umum). Komisi Pemilihan Umum (KPU) and Komisi Pemilihan Umum Daerah (KPUD), both at the provincial and city/district levels, have their respective authorities in the process of organizing general elections. The General Election Commission at the city/district level only has the authority related to the electoral process and electoral law enforcement in the administration of presidential and legislative elections. Meanwhile, the KPU at the central level has the authority in terms of electoral regulation, electoral process, and electoral law enforcement (Prihatmoko, Joko J,2010).

Looking at general election commissions globally, in the UK, a commission like this KPU is called The Electoral Commission which consists of about 5 (five) to 9 (nine) commissioners whose determination is made by the queen based on a proposal from the House of Commons for a term of 10 (ten) ) years ( Didik Sukriono, 2009).

The Queen can dismiss them as well on the proposal of the House of Commons. The Commission is responsible for all processes of holding elections and referendums conducted in the UK, both at the local and national levels. Likewise, the process of redistribution of seats in legislative elections, the process of registering political parties, making rules related to party income and outcomes, campaigns, and party advertisements, both in the mass media and electronic media. All of these things are the responsibility of the Electoral Commission.

In addition to the KPU, there are institutions that also play an important role in the implementation of elections and are closely related to the existence of the KPU, namely survey institutions that carry out quick count processes. Ray Rangkuti, Executive Director of Lingkar Madani (LIMA) assessed that the existence of a quick count is very important in the democratic process in a country (Dani Prabowo, 2020) According to him, there are at least two main functions of quick counts in guarding democracy in Indonesia, first, quick counts serve as information material to find out predictions about who will win the election. He explained that a credible survey institution will also present credible results. Furthermore, the second function of the presence of a quick count is as a guide to control the results of the vote count conducted by the KPU. If there is a significant difference, then it is worth asking whether there was an error in the quick count process (Dani Prabowo, 2020).

As we know today, the existence of survey institutions has emerged and its popularity is very dominant among the public. Various surveys and polls conducted, both in the implementation of the legislative general election and the presidential election, have had a considerable influence in driving public opinion. Likewise, in the general election process held at the local level, both to elect governors and regents/mayors, survey institutions are always at the forefront of conducting surveys and polls. In short, all existing survey institutions have increased in popularity and are quite attractive to many successful teams, both from political parties and potential leaders (Ismatillah A. Nu'ad, 2009). But behind that, the level of popularity of the survey agency is also accompanied by various accompanying debates. For example, the general public has the opinion that the survey agency is not neutral from the political interest of the successful team in winning the candidate it carries. In addition, the performance of the survey institutions is considered only as of the opinion-makers who only want to influence voters to lean towards one of the political parties or leaders who are contesting. In this condition, survey institutions that are expected to foster a climate of public democratization actually spread various fake news and hoaxes through the results of their surveys and polls.

Controversy about the existence of this survey agency was also happening in America (Ismatillah A. Nu'ad In,2009). America, the survey agency is considered to have more interest in business and industrialization, or it can also be called an institution that seeks to lead public opinion by attracting the attention of various mass media rather than revealing the actual public opinion. Gallup Poll, one of the largest survey institutions in the United States, is considered only as a think-tank forming public opinion through surveys and polls it makes (Ismatillah A. Nu'ad In, 2009) Gallup Poll is considered to have played a game by using its power that requires the realization of victory and political power that exists in Uncle Sam's country. (Ismatillah A. Nu'ad In,2009).

Not much different from the reality in a number of developing countries, especially those that are actively building democracy, the existing survey institutions often have doubts about their moral honesty among the people. These survey institutions often receive sharp criticism, one of which is through a poll on the existence of the survey agency itself. As a result, not a few people show an attitude of uncertainty about the performance of survey institutions (Ismatillah A. Nu'ad In,2009). This condition certainly makes people pay less attention and trust to the survey results which are considered no longer independent. It is proven that every time an election is held, survey institutions seem to only lead public opinion to certain contestants. This is certainly very unfortunate considering that the results issued by survey institutions are part of one of the important instruments in a democracy.

\section{Conclusion}

As explained earlier, democracy requires freedom, justice, and regular elections. The next standard is related to election management institutions. In this case, it is obligatory to form an institution in the form of an election management institution that 
has the ability to conduct elections professionally and independently. These standards are essential for the achievement of free and fair elections. The more independent and competent the electoral management body in a country, the greater the opportunity for a country to practice election principles with the support of the people. In a country where the election management body has a very strong influence from the ruling government, the democratization process in that country will certainly be difficult to carry out in a conducive manner.

The General Election Commission (KPU) is an institution that carries out the function of organizing elections in Indonesia. KPU and KPUD, both at the provincial and city/district levels, are independent institutions and have their respective authorities in the process of organizing general elections. The General Election Commission at the city/district level only has the authority related to the electoral process and electoral law enforcement in the administration of presidential and legislative elections. Meanwhile, the KPU at the central level is authorized in terms of electoral regulation, electoral process, and electoral law enforcement.

However, the independence of the KPU should also not be interpreted to the extent that it does not become a direct part of the executive government or its membership is not filled by representatives of political parties. However, independence must also be interpreted as freedom in issuing policies, formulating regulations, and conveying accountability. The freedom possessed by the KPU is not unlimited freedom. However, freedom is in line with the principles of constitutional democracy and the principles of free and fair elections. Even more than that, independence must be interpreted as strength, paradigm, ethics, and spirit to ensure a process and outcome of the election that reflects the interests of the people, nation, and state, now and in the future.

In addition, it is important to hold clear regulations regarding the authorities and responsibilities between the KPU and other supporting institutions, such as Election Supervisory Body in Indonesia called Badan Pengawas Pemilu (Bawaslu), and Election Organizing Honorary Council in Indonesia called Dewan Kehormatan Penyelenggara Pemilihan Umum (DKPP) as well as other institutions that are directly or indirectly related to the KPU as an effort to realize checks and balances between institutions. election organizers.

As explained earlier, democracy requires freedom, justice, and regular elections. The next standard is related to election management institutions. In this case, it is obligatory to form an institution in the form of an election management institution that has the ability to conduct elections professionally and independently. These standards are essential for the achievement of free and fair elections. The more independent and competent the electoral management body in a country, the greater the opportunity for a country to practice election principles with the support of the people. In a country where the election management body has a very strong influence from the ruling government, the democratization process in that country will certainly be difficult to carry out in a conducive manner.

The General Election Commission (KPU) is an institution that carries out the function of organizing elections in Indonesia. KPU and KPUD, both at the provincial and city/district levels, are independent institutions and have their respective authorities in the process of organizing general elections. The General Election Commission at the city/district level only has the authority related to the electoral process and electoral law enforcement in the administration of presidential and legislative elections. Meanwhile, the KPU at the central level is authorized in terms of electoral regulation, electoral process, and electoral law enforcement.

However, the independence of the KPU should also not be interpreted to the extent that it does not become a direct part of the executive government or its membership is not filled by representatives of political parties. However, independence must also be interpreted as freedom in issuing policies, formulating regulations, and conveying accountability. The freedom possessed by the $\mathrm{KPU}$ is not unlimited freedom. However, freedom is in line with the principles of constitutional democracy and the principles of free and fair elections. Even more than that, independence must be interpreted as strength, paradigm, ethics, and spirit to ensure a process and outcome of the election that reflects the interests of the people, nation, and state, now and in the future.

In addition, it is important to hold clear regulations regarding the authorities and responsibilities between the KPU and other supporting institutions, such as Bawaslu, and DKPP as well as other institutions that are directly or indirectly related to the KPU as an effort to realize checks and balances between institutions. election organizers.

\section{Reference}

[1] Budiawan, I. (2008) PolitisasiSurveidanDemokrasi. Malang: PermataHati.

[2] Didik S (2009). Menggagas Sistem Pemilihan Umum di Indonesia, Jurnal Konstitusi. 7(1)

[3] Donald. (1997) Parulian. MenggugatPemilu. Jakarta: PustakaSinarHarapan.

[4] Elmendorf, C. S. (2006). Election Commissions and Electoral Reform: An Overview. Election Law Journal. 5 (4)

[5] Huda, N. and Imam N. (2017). Penataan Demokrasi dan Pemilu di Indonesia Pasca Reformasi. Jakarta: Kencana. 
[6] Irawan, O. S. (2011). Analisis Kedudukan Komisi Pemilihan Umum (KPU) sebagai Lembaga Independen dalam Sistem Ketatanegaraan Indonesia", DINAMIKA HUKUM. 1(2).

[7] Jimly A. (2006). Pengantar Ilmu Hukum Tata Negara. Jakarta: Sekretariat Jenderal dan Kepaniteraan MK RI, [10] Prihatmoko, Joko. PemilihanKepala Daerah Langsung. Yogyakarta: PustakaPelajar, 2005.

[8] Marzuki, S. (2008). PeranKomisiPemilihanUmumdanPengawasPemilu yang Demokratis. Jurnal Hukum, 3(5).

[9] Mozaffar, S and Andreas S. (2002). The Comparative Study of Electoral Governancelntroduction, International Political Science Review.23(1).

[10] Nasef, M. I. (2019). MPR di Persimpangan Jalan: Refleksi Paradigmatik Penguatan Kelembagaan MPR Pasca Amendemen UUD 1945, Istinbath: Jurnal Hukum. 16(2).

[11] Nu'ad, I. A. (2009). MenyoalSisiNegatif Quick Count. Jawa Pos

[12] Prabowo, D. (2020). Ray Rangkuti:Quick Count Penting untuk Mengawal Demokrasi.

[13] Sardini, N. (2011). Restorasi Penyelenggaraan Pemilu di Indonesia. Yogyakarta: Fajar Media Press

[14] Tanthowi, P. U. (2010). Mempertahankan Kemandirian KPU: Antara Produk Legislasi dan Mahkamah Konstitusi, Pustaka Pemilu.

[15] Warjiyati, S. (2019). Penataan Struktur dan Kewenangan Komisi Pemilihan Umum, Badan Pengawas Pemilu dan Dewan Kehormatan Penyelenggara Pemilu Dalam Upaya Mewujudkan Pemilihan Umum yang Demokratis di Indonesia, ARISTO, 8 (1)

[16] Yusuf, M. (2010). Peran Komisi Pemilihan Umum (KPU) dalam Pendidikan Politik. Ganec Swara, 4(1). 